\title{
Методи реабілітаціі хворих після оперативного лікування варикозної хвороби
}

\author{
Н. П. Коржик
}

Консультативно-діагностичний центр Шевченківського району, м. Київ

\section{Methods of rehabilitation in patients after operative treatment of varicose disease}

\author{
N. P. Korzhyk \\ Consultive-Diagnostic Centre of Shevchenkivskyi District, Kyiv
}

\section{Реферат}

Мета. Вивчити вплив медикаментозного та бальнеологічного лікування на перебіг післяопераційного періоду у пацієнтів з варикозною хворобою (ВХ).

Матеріали і методи. Дослідження проведено щодо 70 пацієнтів з ВХ, прооперованих за період з 2006 по 2017 р. Жінок було 44, чоловіків - 26 віком від 31 до 73 років. У 42 із 70 пацієнтів застосовано запропоновану реабілітаційну схему. Результати. Санаторно-курортне лікування покращувало післяопераційний перебіг та запобігало виникненню рецидивів ВХ.

Висновки. Після успішно виконаної венектомії реабілітаційне лікування є обов'язковим і його проведення має бути пунктуальним. Післяопераційна реабілітація за запропонованою схемою покращує клінічний стан хворого, запобігає розвитку ускладнень та рецидиву ВХ.

Ключові слова: варикозна хвороба; операція; рецидив.

Abstract

Objective. To study up the impact of medicinal and balneal treatment on the postoperative period course in patients, suffering varicose disease (VD).

Materials and methods. The investigation was conducted in 70 patients, suffering VD and operated in $2006-2017$ yrs. There were 44 women and 26 men, ageing 31-73 yrs old. In 42 of 70 patients the proposed rehabilitation scheme was applied.

Results. The spa resort treatment have improved postoperative course and prevented occurrence of the VD recurrence. Conclusion. After successfully performed venectomy the rehabilitation treatment is obligatory and its conduction ought to be strictly accomplished. Postoperative rehabilitation in accordance to the scheme proposed improves clinical status of the patient, prevents development of complications and the VD recurrence.

Keywords: varicose disease; operation; recurrence.

Лікарі, виконавши оперативне втручання у хворих 3 $\mathrm{BX}$, не завжди вдаються до застосування реабілітаційних та протирецидивних методів. До того ж державної програми реабілітації хворих після венектомії немає. Проте успішно виконана операція не є гарантією того, особливо за гострого тромбофлебіту, що в ранньому післяопераційному періоді не виникнуть ускладнення у вигляді нагноєння рани, лімфостазу, що призводить до збільшення терміну непрацездатності пацієнта [1]. Тому високий рівень професіоналізму лікаря та санітарна освіта пацієнта мусять бути доповнені проведенням реабілітаційного лікування з метою уникнення можливих рецидивів та ускладнень після операції.

Позитивно діють на нормалізацію мікроциркуляторних процесів у тканинах сучасні венотоніки, зокрема детралекс - єдиний флеботропний препарат, що містить очищену флавоноїдну фракцію (диосмін та гесперидин) у мікронізованому вигляді. Мікронізація (зменшення розмірів частинок активної речовини) забезпечує швидку абсорбцію активного компонента після прийому всередину та швидшу дію у порівнянні з немікронізованою часткою диосміну. Детралекс, одна таблетка якого містить 500 мг очищеної мікронізованої флавоноїдної фракції (диосміну - 90\% та гесперидину - 10\%), є венотонічним та ангіопротекторним засобом, зменшує розтягнення вен, підвищує тонус та зменшує венозний стаз, покращує лімфатичний відтік, зменшує проникність та підвищує резистентність капілярів, покращує мікроциркуляцію, зменшує взаємодію лейкоцитів з ендотелієм, адгезію нейтрофільних гранулоцитів у посткапілярних венулах [2].

Відомо, що венозну систему нижніх кінцівок формують глибокі, поверхневі та комунікантні вени. Всі вони мають клапанний апарат, що забезпечує плин крові у напрямку до серця. Венозний відтік має кілька механізмів, основним з яких є активне скорочення м'язів, що оточуЮть глибокі вени [3].

Гель венорутинол, 1 г якого містить 20 мг венорутинолу у перерахунку на рутин та суху речовину, належить до ангіопротекторів та капіляростабілізуючих засобів з Р-вітамінною активністю, зменшуе проникність та ламкість капілярів, зміцнює стінки вен та капілярів, підвищує тонус гладких м'язів венозних кровоносних судин, чинить протинабрякову, протизапальну та знеболювальну дію [2]. Проте застосування лише медикаментозних препара- 
тів недостатньо з урахуванням того, що 86,5\% пацієнтів 3 ВХ мають патологію хребта, 27,69\% - малого таза, 1,54\% - ендокринної системи [4].

Серед реабілітаційних заходів, направлених на відновлення здоров'я хворих, повернення їх до праці та суспільного життя, важливу роль відводять санаторно-курортному лікуванню. У разі хірургічних захворювань, зокрема BX, воно необхідне щонайменше один раз на рік, ефективніше - один раз на півроку. В Україні є багаті природні оздоровниці. Не раніше ніж через 2 міс після оперативного втручання, якщо немає протипоказань, дієвим $€$ лікування на сірководневих бальнеологічних курортах - Любінь-Великий, Немирів, радонових - Біла Церква, Хмільник, грязевих - Слов'янськ, Бердянськ, Маріуполь, Куяльник, кліматичних приморських - Бердянськ, Аркадія, Великий Фонтан [5, 6].

Мета дослідження: вивчити вплив медикаментозного та бальнеологічного лікування на перебіг післяопераційного періоду у пацієнтів з ВХ.

\section{Матеріали і методи дослідження}

Проаналізовано вплив венотоніків та бальнеологічного лікування на реабілітаційний процес у 70 хворих, оперованих з приводу ВХ. Жінок було 44, чоловіків -26 віком від 31 до 73 років. Оперативні втручання виконували за методами Троянова-Тренделенбурга, Бебкока, Нарата. У залежності від схеми реабілітаційного лікування пацієнтів розподілили на дві групи: основну і порівняльну. До основної групи включили 42 пацієнти, яким після виконаного оперативного втручання призначали реабілітаційні заходи за такою схемою: $з$ першого дня після операції - препарат детралекс по одній таблетці 2 рази на день протягом 60 днів у поєднанні з місцевим застосуванням гелю венорутинол та бальнеологічним лікуванням через 2-6 міс тривалістю 15 - 30 днів, встановленою на основі клінічного досвіду, яку щодо кожного пацієнта визначали індивідуально. 3 метою попередження розвитку рецидиву ВХ запропоновану реабілітаційну схему слід застосовувати один раз на півроку протягом 5 років.

Порівняльну групу склали 28 пацієнтів, яким системно призначали препарат троксевазин у вигляді капсул у поєднанні з місцевим застосуванням гелю троксевазин, що сприяло зменшенню проявів венозної недостатності.

\section{Результати}

На основі клінічного досвіду та даних лабораторних досліджень встановлено, що запропонований спосіб реабілітації покращував перебіг післяопераційного періоду та попереджав розвиток ускладнень захворювання. Спосіб простий, його можна використовувати в амбулаторних та стаціонарних умовах.

У хворих основної групи під час лікування зазначеним способом біль та набряки зменшились, післяопераційні рани загоїлись первинним натягом. Через 30 днів стан хворих нормалізувався повністю. У хворих порівняльної групи, як показав ретроспективний аналіз іх амбулаторних карток, стан покращувався через 2 - 2,5 міс.

\section{Обговорення}

Основною відмінністю способу післяопераційного протирецидивного лікування хворих з ВХ є системне застосування препарату детралекс у поєднанні з місцевим призначенням венорутинолу у вигляді гелю та бальнеологічним лікуванням, яка полягає у забезпеченні дезагрегуючої, протизапальної та венотонізуючої дії, що оптимізуе реабілітаційне лікування хворих після венектомії та попереджує розвиток рецидивів та ускладнень. Санаторнокурортне лікування посідає важливе місце в комплексному реабілітаційному лікуванні ВХ, оскільки сприяє покращенню післяопераційного перебігу та запобігає виникненню рецидивів.

\section{Висновки}

1. Після успішно виконаної венектомії реабілітаційне лікування є обов'язковим і його виконання має бути пунктуальним.

2. Запропонована схема післяопераційної реабілітації дозволяє покращити клінічний стан хворого, уникнути ускладнень та рецидивів ВХ.

\section{References}

1. Bilayeva O, Korzhyk NP, Nechta VV. Viznachennia docilnosti viconaniia venectomii u hvorih na hostriy trombophlebit ven niznih kincivok. In: Problemni pitanna medicine nevidcladnich staniv. Materiali naukovoho simpoziumu. Kyiv; 2010, 35-8. [In Ukrainian].

2. Kompendium, Lecarstvennie preparati, 2012. [In Ukrainian].

3. Vaschenko M. Venoplant $\mathrm{v}$ lechenii chronicheskoi venoznoi nedostatochnosti. Liki Ukraini. 2004;(4):1-2. [In Ukrainian].

4. Korzhyk N. P. Varicose disease of the lower extremities: causes, complications, choice of methods for treatment and prophylaxis. Klin khir 2016;(2):52-5. [In Ukrainian].

5. Mazuryk MF, Demianuk DH. Ambulatorna khirurhiia. Kyiv: Zdorovia; 1988. 302 s.[In Ukrainian].

6. Korzhyk NP, Myronov OM. Ambulatorna khirurhiia. Kyiv: Knyha-plius; 2010. 240 s. [In Ukrainian]. 